\title{
Secondary Boycotts and Work Preservation
}

\section{In 1947, and again in 1959, Congress amended the National Labor}

Relations Act to forbid "secondary" union activity. Section 8(b)(4)(B), a part of the Taft-Hartley Act," prohibits union activity which forces an employer to cease using, selling, or transporting products of any other employer. The Landrum-Griffin Act ${ }^{3}$ added Section 8(e), which extends this prohibition to cover agreements or contracts providing for such cessations. Read literally, the two sections would repeal the Wagner Act ${ }^{5}$ by banning all union strikes or boycotts, since any of these activities necessarily forces the cessation of some business. Clearly, Congress intended to proscribe some activity, but there is no reason to conclude that it intended to emasculate the right to strike. History of the passage of the sections reveals no precise or even discernible distinction between permitted and proscribed activities. ${ }^{\circ}$

Faced with this dilemma, courts have relied upon the sparse congressional history, common law doctrines of secondary boycotts, and their own wits to fashion a line between prohibited (secondary) activity and lawful (primary) activity. The distinction which emerged from twenty years of decisional law was filled with contradictory reasoning and judicial hair-splitting. In the past few years, however, confusion has partially given way to a consistent rationale that seems to reflect the central concerns of Congress and offers a relatively clear and predict-

1. 29 U.S.C. $\$ 158(b)(4)(B)$ (1964) reading in pertinent part:

It shall be an unfair labor practice for a labor organization or its agents . . (4) to engage in, or to induce or encourage any individual employed by any person engaged in commerce ... to engage in, a strike or a refusal in the course of his emplojment to use, manufacture, process, transport, or otherwise . . . handle or work on any goods, articles, materials, or commodities or to perform any services ... where . . . an object thereof is-(B) forcing or requiring any person to cease using, sclling, handling, transporting, or otherwise dealing in the products of any other producer, processor, or manufacturers, or to cease doing business with any other person, of forcing or requiring any other emplojer to recognize or bargain with a labor organization as the representatives of his employees ... Provided, That nothing contained in this clause (B) shall be construed to make unlawful, where not otherwise lawful, any primary strike or primary picketing.

2. Labor Management Relations Act, 61 Stat. 136 (1947).

3. Labor Management Reporting and Disclosure Act of 1959, 73 Stat. 519.

4. 29 U.S.C. $\$ 158(e)$, reading in pertinent part:

It shall be an unfair labor practice for any labor organization and any cmplojer to enter into any contract or agreement, express or implied, whercby such emplojer ceases or refrains or agrees to cease or refrain from handling, using, selling, transporting or otherwise dealing in any of the products of any other emplojer, or to cease doing business with any other person. ...

5. 49 Stat. 449 (1935). Section 13 of the Wagner Act, 29 U.S.C. \$ 163, preserves the right to strike; Section 7, 29 U.S.G. \$ 157, preserves the right to bargain collectively.

6. See note 42 infra. 
able rule of law. ${ }^{7}$ Congress apparently desired to limit the disruptive effects of legitimate employer-employee confrontations and protect neutral parties from being engulfed in the contest between the disputants for tactical advantage. The new rationale both limits union demands to those which are necessary to further only the interests of the bargaining unit, although ancillary effects of the demands are permitted, and limits bargaining unit activity to a direct confrontation between the immediate parties ${ }^{8}$ to the dispute, while recognizing that this confrontation may have side effects. ${ }^{0}$

Until 1967 the courts had touched only sporadically on the question whether product boycotts for the purpose of work preservation are primary or secondary. The previous discussion by courts threw little light on the problem: it dealt with the scope of legitimate union activity in furtherance of traditional labor goals, whereas work preservation involves the legitimacy of a new union goal. In the few cases to present the issue, the judges have tended to apply the traditional primary-secondary rules without regard to the distinguishing characteristics of the work-preservation situation.

I.

The early work-preservation cases failed even to raise the suggestion of legitimate primary activity. In Wadsworth ${ }^{10}$ the Tenth Circuit held that a strike against the use of prefabricated houses violated section 8 (b)(4)(B) on a literal reading of the statutory language forbidding a refusal to handle goods. Similarly, in General Millwork, ${ }^{11}$ the Sixth

7. See, e.g., National Woodwork Mfg. Ass'n v. NLRB, 386 U.S. 612 (1967); Orangc Bclt District Council of Painters v. NLRB, 328 F.2d 534 (D.C. Cir. 1964); Ohio Vallcy Carpenters Dist. Council (Cardinal Industries), 136 N.L.R.B. 977 (1962). Lesnick, Job Securily and Secondary Boycotts: The Reach of NLRA $\S \S 8(b)(4)$ and $\$(e), 113$ U. PA. L. REV. 1000 (1965); Aaron, The Labor-Management Reporting and Disclosure Act of 1959, 78 HARv. L. REv. 1086 (1960); Cox, The Landrum-Griffin Amendments to the National Labor Relations Act, 44 MINN. L. REv. 257 (1959).

8. The immediate parties are the complaining bargaining unit and the employer whose action will satisfy ultimate union demands.

9. This formula purposely avoids the more traditional and confused language of secondary boycott reasoning. The linguistic contortions involved in distinguishing "aims," "objects," and "hopes" seem of little use. The definition rejects this scarch for motive and limits both the scope of demands and activity with reference to the bargaining unit itsclf, This covers the two types of secondary behavior: (1) the use of the immediate employer as a conduit of union pressure to change the labor policy of suppliers or customcrs; and (2) the expansion of a primary dispute through tactical pressure upon supplicrs or customers.

10. NLRB v. United Bhd. of Carpenters \& Joiners, 184 F.2d 60 (10th Cir. 1950), en. forcing 81 N.L.R.B. 802 (1950), cert. denied, 341 U.S. 947 (1951).

11. NLRB v. Carpenters Local 11, 242 F.2d 932 (6th Cir. 1957), enforcing 118 N.L.R.B. 1084 . 
Circuit decided without primary-secondary discussion that a refusal to handle pre-hung doors in order to enforce provisions in the collectivebargaining agreement was an illegal stoppage under Section 8(b)(4)(B); the court merely assumed the agreed-upon clause to be a "hot cargo" type used in furthering a dispute with the boycotted company, without asking its purpose or against whom the union had in fact aimed the stoppage.

Later cases reflected a growing judicial awareness of the primarysecondary dichotomy and an increasing sense of obligation to justify $8(\mathrm{~b})(4)(B)$ decisions with at least a reference to congressional intent. Unfortunately, initial recognition of the need to separate permitted from prohibited activity antedated by about ten years the arrival of a partially coherent statement of the principle. During the interim courts grossly misapplied the primary-secondary theory, usually to the disadvantage of the union.

A classical abuse of primary-secondary reasoning in the boycott area involved the "cease doing business" fallacy, in which the courts found an unlawful secondary objective whenever the strike or boycott led to a cessation of business. Since any effective strike or boycott forces the employer against whom it is directed to cease doing some business, the argument effectively nullified the right to strike. As late as 1958 the Supreme Court suggested the continuing vitality of such reasoning in Sand Door, ${ }^{12}$ a hot-cargo case arising under Section $8(\mathrm{~b})(4)(B)$ before the enactment of Section 8(e). Although the facts clearly revealed secondary behavior and the Court was careful to note that it would not read the statute to proscribe all strikes, the "cease doing business" language still appeared without further elaboration..$^{13}$ Applying the rule to work preservation, the Ninth Circuit in Sound Shingle ${ }^{\text {st }}$ treated a union refusal to handle Canadian shingles as secondary without pausing to inquire into the purpose of the refusal or against whom it was aimed, even though the record suggested a union concern to protect jobs from foreign competition. And in Joliet Contractor's Association v. $N L R B,{ }^{15}$ the Seventh Circuit affirmed the Board's finding of a Section $8(\mathrm{~b})(4)(\mathrm{B})$ violation where glaziers refused to install preglazed glass in residential construction work. Overruling the admittedly obscure and at times contradictory findings of the trial examiner that the

12. Carpenters Local 1976 v. NLRB, 357 U.S. 93 (1958).

13. Id. at 98 .

14. NLRB v. Washington-Oregon Shingle Weavers' Dist. Council, 211 F.2d 149 pth Cir. 1954).

15. 202 F.2d 606 (7th Cir. 1953). 
refusal amounted to primary conduct because intended for work preservation, ${ }^{16}$ the court of appeals rejected both this union defense and the primary-secondary scheme generally, using instead the cease-doingbusiness test.

The staunchest adherent to the cease-doing-business argument has been the Labor Board itself. In MacDonald-Scott, ${ }^{17}$ union employees refused to install prefabricated sections of underground tunnel for missile silos, claiming a deprivation of traditional jobs. The Botrid held the refusal illegal under Section $8(\mathrm{~b})(4)(B)$ without mentioning regular primary or secondary matters because of the union intent to sever the business connection between the contractor and the tunnel section supplier. The Board found what it termed the "work assignment" question inseparable from the illegal product boycott. In another missile case, Martin Company, ${ }^{18}$ the Board resolved an obvious work-preservation dispute by finding a Section $8(\mathrm{~b})(4)(\mathrm{B})$ violation in the union's intent to end the use of prefabricated missile launching cables.

By the 1960's the courts had come to reject the cease-doing-business analysis as a talisman in the area, only to find that they had forcibly to impress their learning on an unreceptive Board. Where a grocery clerk's union attempted to preserve supermarket shelving for itself, the District of Columbia Circuit refused to accept the NLRB's finding of business-cessation motive as an adequate ground for a Section $8(b)(4)(B)$ violation. ${ }^{\text {to }}$ And in 1964 the Third Circuit had to overrule the Board and decide that a union refusal to allow subcontractors to drill telephone-pole holes with power augers was primary activity. ${ }^{20}$

Another mistaken approach, which misled the courts almost as much as the cease-doing-business test, turned on the language in Section $8(\mathrm{~b})(4)(B)$ which prohibits action "an object" of which is the cessation of business. In NLRB v. Denver Building and Construction Trades Coun$c^{2} l^{21}$ the Supreme Court held that where one object of a strike was secondary, the entire activity was unlawful even if all other objects were primary. Since all foreseeable results of the strike were considered

16. Glazier's Local 27, 90 N.L.R.B. 542, 554, 555 (1950).

17. Plumbers Local 598, 131 N.L.R.B. 787 (1961).

18. Electrical Workers Local 756, 181 N.L.R.B. 1010 (1961).

19. Retail Clerks Local 770 v. NLRB, 296 F.2d 368 (D.C. Cir. 1961), remanding 127 N.L.R.B. 1522.

20. NLRB v. Operating Engineers Local 325 (Nichols Elec. Co.), 326 F.2d 218 (\$d Cir. 1964), remanding 138 N.L.R.B. 540 (1962). The battle continued as the Eighth Circuit had to strike down ah NLRB "cease doing business" ruling in American Boiler Mfg. V. NLRB, 366 F.2d 815 (8th Cir. 1966), reversing in part 154 N.L.R.B. 285 (1965).

21. 341 U.S. 675 (1951). 
"objects" within the statute,22 Denver Building threatened to bar primary activity whenever it generated ancillary effects-which was to say, always. Ten years later the Court corrected itself sub silentio in General Electric, ${ }^{23}$ validating picketing at a gate reserved for independent contractors. Mr. Justice Frankfurter's majority opinion dismissed the disruption of business with the contractors as a natural ancillary result of the primary picketing not "infecting" the legitimate action. The picketers "hoped" to halt the business, but that was not their "object."24

Word of the change of emphasis in the General Electric decision must have been slow to reach the Midwest, however, for three years later the Seventh Circuit relied on the Denver Building logic to dispose of a work preservation case. In NLRB v. Milk Wagon Drivers Local $753^{25}$ the union was fighting to preserve its right to deliver to dairies in the Chicago area; the interruption of contract relations between milk suppliers and dairies was held a secondary object, ${ }^{n B}$ overriding any primary work-preservation goals. ${ }^{27}$

Within the past few years, the courts have come to apply a more carefully thought-out primary-secondary rationale to the work-preservation cases. The development of stable criteria in identifying secondary activity has led the judges to distinguish three classes of workpreservation situations: ( 1 ) subcontracting cases, in which the union seeks to preserve its jobs by limiting the conditions under which the employer may contract out work; (2) specific job allocation cases, in which the union insists that tasks or work assignments be reserved for its members; and (3) product boycott cases, in which the union promotes job security by preventing the introduction of prefabricated materials.

1. Subcontracting. In a brace of 1964 decisions the District of Columbia Court of Appeals rejected the existing primary-secondary approach, differentiated subcontracting from other work-preservation situations, and established clear criteria for identifying secondary behavior in the area. In Orange Belt District Council of Painters No. 48

22. Id. at 689 .

23. Local 761, UEW v. NLRB, 366 U.S. 667 (1961).

24. Id. at $673-74$.

25. 335 F.2d 326 (7th Cir. 1964).

26. Id. at 328.

27. See also NLRB v. Local 12, Int'I Union of Operating Engineers, 293 F.2d 319 (9th Cir. 1961), enforcing 126 N.L.R.B. 688 (1960). The most recent use of this discredited theory is by Mr. Justice Stewart, dissenting in National Woodwork MIfg. Ass'n v. NLRB, 386 U.S. 612, 651 (1967), citing Denver Bldg. Trades and MfacDonald-Scott, discussed supra pp. 1404-05. 
v. $N L R B,{ }^{28}$ the court remanded for further findings by the Board, rejecting the agency's determination of a Section $8(b)(4)(B)$ violation arrived at without discussion of the purpose of the disputed contract clause. Judge Wright indicated that a subcontracting clause providing that only organized plants receive contracted-out work would be secondary, because it would reach beyond the immediate employer-employee relationship to promote the status of unions generally without protecting bargaining-unit jobs. But, he continued, a clause requiring that subcontracted employees be paid union wages and benefits without regard to union membership would be primary, since it would affect peripheral parties only to the extent necessary to protect bargaining-unit jobs by removing the employer's incentive to "farm out" work at lower wages. ${ }^{29}$ In Truck Drivers' Local 413 v. $N L R B, 30$ the court flatly reversed the Board to hold primary a subcontracting clause providing for union wages and benefits for all hired employees. The court designated this type of contract term a "union standards" clause ratifying its primary-activity status the following year in Lewis $v . N L R B .^{31}$

2. Job Allocation. A second area of work-preservation disputes involves specific job allocation or reservation of work. Here the concern is not the conditions under which the employer may give work to others, but who within the plant may have the jobs reserved. Union insistence upon the employer's guaranty of work to bargaining-unit members, no matter what the consequent disruptive effects upon other parties, is primary because its effects are ancillary to the direct confrontation of primary parties. But a demand for work preservation for the local or sister unions, regardless of their relationship to the cmployer, is secondary because it is not limited to the alteration of a primary relationship.

Judicial recognition of the job-allocation clause as a special problem in the work-preservation field appeared in Meat Drivers Local $710 v$. $N L R B$ (Wilson \& Co. ${ }^{32}$ where the District of Columbia Court of Appeals allowed meat packing drivers to reacquire and preserve work for themselves without regard to the serious disruption their demand inflicted on meat suppliers. At the same time, the NLRB had adopted a similar approach to work allocation on its own hook. In contrast to its

28. 328 F.2d 534 (D.C. Cir. 1964).

29. Id. at 538-39.

30. 334 F.2d 539, 548 (D.C. Cir.) (Wright, J.), cert. denied, 879 U.S. 916 (1964).

31. 350 F.2d 801 (D.C. Cir. 1965), upholding the union standards clause (so named at 801) of the National Bituminous Coal Wage Agreement.

32. 335 F.2d 709 (D.C. Cir. 1964) Again Judge Wright pioneered, using the same principles he formulated for subcontracting cases. 
recalcitrance and confusion in subcontracting cases, the Board declared in four recent work allocation decisions that reserving work for bargaining-unit members was primary activity. ${ }^{33}$

3. Product boycotts. The primary-secondary test in the boycott area turns on the union's reason for rejecting products. Where the union turns away all goods threatening or replacing bargaining-unit jobs, whether or not manufactured by fellow unionists, the disruption is ancillary to a primary confrontation. But where rejection is limited to non-union goods, an impermissible practice arises from the boycotters' efforts to affect a secondary employer-employee relationship.

In 1967 the Supreme Court dealt directly with the questions raised by product boycotts. ${ }^{34}$ National Woodwork Manufacturers Association v. $N L R B,{ }^{35}$ on certiorari from the Seventh Circuit, involved a strike by carpenters who, acting pursuant to their collective bargaining agreement, refused to hang pre-fitted doors. In Houston Insulation Contractors Association $v$. $N L R B,{ }^{36}$ a companion case from the Fifth Circuit, the union refused to handle pre-cut steel bands, invoking its contract forbidding prefabrication of pipe insulation. Both cases contained substantial evidence that the striking workers were not concerned with the union status of the employees who had manufactured the prefabricated products, and that they would have rejected such material from any source.

The main body of the majority opinion in Woodwork is concerned with reconciling Section $8(e)$ and $8(\mathrm{~b})(4)(B)$. The Court held that Congress had added Section 8(e) to plug a loophole suggested by the Sand Door $^{37}$ decision: that union contracts with "hot cargo" clauses would be permissible under $8(\mathrm{~b})(4)(\mathrm{B}) .^{38}$ Both majority and minority in

33. Milk Drivers Local 546 (Minnesota Mfilk) 133 N.L.R.B. 1314, 1316 (1961); Teamsters Local 282 (Precon Trucking), 139 N.L.R.B. 1077, 1084 (1962) (decision on other grounds); Milk Wagon Drivers Local 603 (Drive-Thru Dairy), I45 N.L.R.B. 445, 449 (1963); Dairy Workers Local 83 (Arthur Elias), 146 N.L.R.B. 716, 722-23 (1964).

34. Before 1967 only one NLRB decision, Ohio Valley Carpenters Dist. Council (Cardinal Industries), 136 N.I.R.B. 977 (1962), enforced, 339 F.2d 142 (7th Cir. 1969), attempted to apply a rational primary-secondary schema to the situation. Although finding a secondary violation, the Board held that it would have been primary had the union rejection of supplier materials been motivated by the desire to preserve jobs. Cf. Meat Drivers Local 710, 143 N.L.R.B. 1221, 1237-42 (1963) (dissenting opinion of ifember McCulloch). The two conflicting circuit court decisions on this point, National Woodwork Mfg. Ass'n v. NLRB, 354 F.2d 594 (7th Cir. 1960) (ignoring the new rationale) and Houston Insulation Contractors Ass'n v. NLRB, 357 F.2d 182 (5th Cir. 1960) (using the new rationale) were resolved by the Supreme Court as discussed infra.

35. 386 U.S. 612 (1967).

36. 386 U.S. 664 (1967).

37. Carpenters Local 1976 v. NLRB, 357 U.S. 93 (1958).

38. In Sand Door the Court had pointed out in dicta that $8(b)(4)(B)$ forbade union activity of a secondary nature unless provided for in contracts allowing union members 
Woodwork agreed that 8 (e) should be read in pari materia with 8 (b) (4)(B) and should therefore be limited by the primary-secondary distinction, even though the section does not contain any explicit provision to that effect. ${ }^{39}$

But Woodwork and Houston also considered the problem of product boycotts for work-preservation, though here unanimity disappeared. The Court's treatment of the issue was distinctly cavalier; in the midst of surveying judicial construction of section $8(b)(4)(B)$ and explaining the significance of the garment-industry's exception from Section 8(e), Mr. Justice Brennan simply assumed that work preservation should be treated like all other union behavior-limited only by the primary-secondary rationale:

[I]f the body of [section $8(e)]$. . . were construed to prohibit primary agreements and their maintenance, such as those concerning work preservation, the proviso would have the highly unlikely effect, unjustified in any of the statute's history, of permitting garment workers, but garment workers only, to preserve their jobs against subcontracting or prefabrication. ${ }^{40}$

From that point onward, the Court discusses work-preservation, not primary and secondary activity in general. It outlines a test for primary activity in the product-boycott area fully in accord with the solutions already worked out above for the subcontracting and job-allocation problems. ${ }^{41}$ Woodwork thus rounds out the primary-secondary rules for the major work-preservation areas. ${ }^{42}$ The attitude it expresses to-

to refuse to handle goods in order to effect a secondary boycott (the "hot cargo" clauses). 357 U.S. at 99.

39. 386 U.S. at 635 (majority), 660 (minority).

40. Id. at 638 (emphasis added).

41. Id. at $644-46$.

42. The majority decision reviews the passage of Section $8(b)(4)(B)$ and Section $8(c)$ at great length, 386 U.S. 623-42, discussing congressional intent regarding secondary activity, and can find little reference to work-preservation, let alone product boycotts. The Court thus interprets silence to mean that no action was intended. Justice Harlan brilliantly summarizes in his concurring memorandum opinion:

We are thus left with a legislative history, which, on the precise point at issuc [work preservation], is essentially negative, which shows with fair conclusiveness only that Congress was not squarely faced with the problem these caseg present. In view of Congress' deep commitment to the resolution of matters of vital importance to management and labor through the collective bargaining process, and its recognitlon of the boycott as a legitimate weapon in that process, it would be unfortunate wero this Court to attribute to Congress, on the basis of such an opaque record, a purpose to outlaw the kind of collective bargaining and conduct involved in these cases. Especially at a time when Congress is continuing to explore methods for meeting the economic problems increasingly arising in this technological age from sclentific advances, this Court should not take such a step until Congress has made unmistakably clear that it wishes wholly to exclude collective bargaining as one avenue of approacly to solutions in this elusive aspect of our economy.

386 U.S. at 649-50. It should be noted that the logic of the dissent is inexplicable: for 
wards work-preservation generally should be taken as a signal to the lower courts and the Board that the Justices will no longer tolerate hostility toward the work-preservation form of union activity in the guise of secondary reasoning.

Not only does the Woodwork decision fill a missing gap in the judicial construction of Section $8(\mathrm{e})$ and $8(\mathrm{~b})(4)(\mathrm{B})$; it is also consistent with surrounding decisional law. Most important in this respect is Fibreboard Paper Product $v . N L R B,{ }^{43}$ where the Court held that an employer's contracting-out of work came within the "terms and conditions of employment" of Section $8(d)^{44}$ and so was subject to mandatory bargaining under Section 8(a)(5). ${ }^{45}$ It would have been anomalous, to say the least, for the Court to have held in Woodwork that provisions over which the employer must bargain under Section 8(d) could not legally be included in their contracts under Section $8(e) .40$

II.

Despite Woodwork's confirmation of the primary-secondary rationale throughout the work-preservation field, lower courts and the NLRB have yet to apply this rationale to create a consistent body of decisional law; consequently, several areas of serious difficulty remain.

secondary activity generally, sweeping prohibitory language is undermined by obvious congressional desire to limit banned activity; with boycotts this same language combined with no evidence of differing intent rests untouched.

43. 379 U.S. 203 (1964).

44. 29 U.S.C. \$ I58(d) defining collective bargaining and its required scope.

45. 29 U.S.C. \& 158(a)(5), making it an unfair labor practice to refuse to bargain collectively. Timken Roller Bearing Co., 70 N.L.R.B. 500 (1940), enforcement denied on other grounds, 161 F.2d 949 (6th Cir. 1947).

46. Fibreboard has been construed to apply to limited situations only. NLRB v. Adams Dairy, 350 F.2d 108 (8th Cir. 1965), held Fibreboard inapplicable to a large operational change in production; NLRB v. Royal Plating \&: Polishing, 350 F.d 191 (3rd Cir. 1965), and NLRB v. Burns Int'I Detective Agency, 346 F.2d 897 (8th Cir. 1965), both held that no bargaining was required when a total cessation of business in a productive unit orcurred. These decisions leave Fibreboard enforcing mandatory bargaining when relatively small changes in the employment of manpower are made, i.e., in work-preservation situations.

United Steelworkers v. Warrior \& Gulf Navigation Co., 363 U.S. 574 (1960), construed a contract arbitration clause to include binding decisions over contracting out of work because of the general National Labor Relations Act scheme. 363 U.S. at 584. And Tcamsters Local 24 v. Oliver, 358 U.S. 283 (1959), found that contracting out work to aroid paying union wage levels was an issue that was subject to required collective bargaining under Section 8(2)(5). 363 U.S. at 294.

A series of NLRB decisions dealing with compulsory settlement of jurisdictional disputes under Section 10(k), 29 U.S.C. \& $160(\mathrm{k})$, included work-preservation issues. Local 26, Int"1 Fur \& Leather Workers, 90 N.L.R.B. 1379 (1950) (work allocation); National Ass'n of Broadcast Engineers, 105 N.L.R.B. 355 (1953) (work allocation); Local 48, Sheet Metal Workers Int'1, 119 N.L.R.B. 287 (1957) (contracting out to avoid union wage levels). The Supreme Court relied upon these cases in NLRB v. Radio Engineers Local 1212, 364 U.S. 573 (1961) to hold $10(k)$ settlement included work allocation disputes which belonged in the collective bargaining scheme of the National Labor Relations Act. 304 U.S. at 577, \& n.12. 


\section{A. Work acquisition}

Although no court has yet addressed itself squarely to the issue, past opinions erroneously suggest that work-acquisition efforts are secondary per se. Woodwork approached the matter by recourse to a "sword and shield" analogy;" and delighted as one might be at this foray into metaphor, the legal basis for the distinction does not exist. The Court reasoned that in the case at hand the carpenters had attempted to preserve work they had traditionally done, which action was defensive (a "shield") and therefore primary. In contrast, the Court said that the boycotts in Allen Bradley ${ }^{48}$ had been illegal because the electrical workers were seeking new jobs-using the boycott offensively (a "sword"). This is wrong; the boycott in Allen Bradley was secondary because it was aimed at preserving jobs for workers in another industry, having nothing to do with whether they were old or new. Further, the jobs sought had previously been performed by the Local before the Depression. As the dissent acidly noted, the sword and shield analogy had been created out of thin air..$^{40}$ Even on its own terms, the proposed sword-shield argument is unpersuasive in its intimation that any seeking after new work is inherently secondary. A union attempt to gain new work strictly limited to the immediate employer-employee context threatens none of the injury to outside parties that the secondary prohibition supposedly guards against. The prohibition of job acquisition is an example of courts using a restriction upon the scope of union activities to ban certain labor goals.

So far, however, the argument that work acquisition should be assimilated to the general primary-secondary context has been unavailing. The NLRB disapproved the efforts of the Chicago meat drivers to reacquire jobs lost as businesses moved to the suburbs by characterizing the union attempt as one to take new work and therefore inherently secondary, even though the employment sought was of the same nature as that currently performed. ${ }^{50}$ The District of Columbia Court of Appeals reversed on the narrow ground that the union efforts con-

47. 386 U.S. at 630 .

48. Allen Bradley Co. v. Local 3, UEW, 325 U.S. 797 (1944).

49. 386 U.S. at 657 .

50. Meat Drivers Local 710 (Wilson \& Co.), 143 N.L.R.B. 1221 (1963). But see the unavailing dissenting opinion of Member McCulloch:

... [T] he Union may insist on bargaining with the packers with respect to contractual provisions which are designed to retain, reclaim, or obtain work of the type now being performed by unit members, despite the possibility that a successful in. sistence in that respect might entail changes in the present relationship between the packers and the independent haulers [emphasis added]. . . . Id. at 1237 . 
stituted an attempt at "recapture" and accordingly were primary; the work, it said, fell within the bargaining unit and was fairly claimable, apparently meaning that the work previously performed must be of the same general nature and closely related to the present scope of the bargaining unit activity. ${ }^{51}$

The District of Columbia reversal has shaken the Board's attitude somewhat. Prior to the holding, the Board had been consistently rigid in its application of the work-acquisition ban. 52 But in United Dairy"3 the agency allowed the union the right to perform work newly acquired by the employer even though formerly performed by non-union men. And recently the Board has gone further, describing an agreement "designed to preserve, obtain, or reacquire [work of the] employees in this unit," as one to preserve work and so "outside the scope of Section 8(e)." "54

The gravest concern in the work-acquisition area is that the courts will limit the permissible scope of job acquisition to work that the unit has traditionally performed. 55 If the unit grows stronger and can move into new productive stages, or if technological change requires employee retraining, nothing in the primary-secondary rationale justifies forbidding the union to claim and preserve the jobs. ${ }^{\text {to }}$

On the other hand, the Board should be careful not to permit the excuse of work preservation and acquisition to disguise secondary activity. In International Association of Heat is Frost Insulators, where the union defended a charge of boycotting non-union prefabricated pipe covering with a work-preservation rationale, the Board correctly found a secondary purpose after ascertaining that it was impossible for the union's members to perform the work claimed because they lacked the requisite skills and because the required machinery

51. Meat Drivers Local 710 v. NLRB, 335 F.2d 709, 713, 716 (D.C. Cir. 1964). A more conservative attitude is represented by Highway Truckdrivers Local 107 v. NLRB, 302 F.2d 897 (D.C. Cir. 1962), holding that a cessation of business from the possibility of work acquisition was enough for a secondary violation.

52. Teamsters Local 282 (Precon Trucking Corp.), 139 N.L.R.B. 1077, 1088 (1962); Milk Wagon Drivers Local 603 (Drive-Thru Dairy), 145 N.L.R.B. 445 (1963).

53. Dairy Workers Local 83 (Arthur Elias), 146 N.L.R.B. 716 (1964).

54. Pipefitters Local 455, 154 N.L.R.B. 285, 288.89 (1965), modified on other grounds, sub nom. American Boiler Mfrs. v. NLRB, 366 F.2d 815 (8th Cir. 196б). Cf. Pipefitters Local 455, 167 N.L.R.B. No. 79, 66 L.R.R.M. 1098 (Sept. 27, 1967); Pipefitters Loeal 539, 167 N.L.R.B. No. 80, 66 L.R.R.M. 1102 (Sept. 27, 1967).

55. This could result from the conservative use of the jobs "fairly claimable" formula. See pp. 1410-1I supra; MicLeod v. Teamsters Local 282, 241 F. Supp. 831, 842 (E.D.N.Y. 1964).

56. If movement to a new area raises jurisdictional problems, section 10(k), 29 U.S.C. $\$ 160(k)$, already offers employers protection.

57. 139 N.L.R.B. 688, 701 (1962). 
could not be used at the job site; the only employees capable of doing the job were non-unit, non-site workers. ${ }^{.8}$

\section{B. Bargaining-Unit Size}

A second area of difficulty involves the limits of the employee group which the work-preservation agreement may legally protect. At one extreme, protecting job opportunities in an already-defined bargaining unit is primary, as reflected in the generally accepted test for "jobs fairly claimable by the appropriate bargaining unit"; at the other, a product boycott to preserve jobs for unionism generally is secondary in that it seeks to cover the working conditions of employees beyond the immediate employer-employee relationship. Between these extremes, however, lie numerous pitfalls.

One problem has arisen in the construction industry litigation. Courts have hinted at limiting protection to the job site, perhaps because of a mistaken reliance on a Section $8(\mathrm{e})$ proviso; ${ }^{50}$ but the concept of primary activity easily includes a boycott or strike by jobsite workers to protect the work of offsite members within the same bargaining unit. Unit work is, after all, unit work; and any member liable to be assigned to a job on or off the site retains a direct interest in protecting both job opportunities. But the argument goes no further. It does not permit the unit to insist that the prefabrication be done by a sister local or a union in general; ${ }^{60}$ the unit must either reserve the work for itself, or impose no restrictions.

Identity of interest between a national union and its local gives rise to a second difficulty. In two cases ${ }^{61}$ the NLRB has held that a local's boycott of work done outside the shop was secondary because the nit* tional had initiated it and it furthered the national's goals. Both cases contained evidence that the local sought to protect jobs outsicle the unit and that no unit job was threatened, but the Board's language went too far. Where the local seeks to prevent a future threat to its security, even at the urging of a national whose insight into long-term technological change is probably superior, its conduct is primary un-

58. See also International Ass'n of Heat \& Frost Insulators, 139 N.L.R.B. 650 (1969); International Ass'n of Heat \&: Frost Insulators, 137 N.L.R.B. 1410 (1962).

59. 29 U.S.C. \& 158(e); the first proviso was added to insure that there were no non. union workers of any employer on the job site.

60. Ohio Valley Carpenters Dist. Council (Cardinal Industries), 136 N.L.R.B. 977, 986. 87 (1962).

61. Baltimore Lithographers Local 2-P (Alco-Gravure) 160 N.L.R.B. No. 90, 63 L.R.R.M. 1126 (Sept. 22, 1966); New York Lithographers Local 1-P (Alco-Gravure), 160 N.L.R.B. No. 91, 63 L.R.R.M. 1129 (Sept. 22, 1966). 
less the employer can adduce evidence of a purpose unrelated to unit needs. Nothing in the primary-secondary analysis requires the Board to penalize union foresight or a joint effort to avoid unemployment, so long as each unit fights for its own jobs. ${ }^{02}$

A third complication occurs where two unions seek to aid each other by preserving work offered by the same employer. The Supreme Court in Houston Contractors ${ }^{63}$ followed two appellate-court decisions ${ }^{\text {it }}$ holding such conduct primary. There the employer required Local 22 to make prefabricated insulation in his home shop for use at the jobsite; the union had negotiated a work-preservation agreement. At the jobsite, Local 113 refused to install prefabricated insulation not made by Local 22, insisting on the right to enforce Local 22's bargaining agreement by virtue of its own job-security clause in the contract permitting mutual aid. Although the Court could have rested on the contract provision, it chose instead to invoke the broader ground that the traditional right of mutual aid and protection of fellow employees enabled each employee to come to the assistance of fellow employees of the same employer even where his own job was not in jeopardy. ${ }^{\text {DS }}$ The decision widens the bargaining unit to comprehend all the employees of any one employer, without regard to whether the various union locals actually engage in joint bargaining. Primary-secondary doctrine may not require such a result; but given the Labor Act's proclivity for a rough parity in bargaining strength between employer and employee, it should not preclude such an outcome.

The "area" job protection cases present a fourth, and most troublesome, question: whether one unit may protect the jobs of surrounding units where they all face a common threat and individual employees frequently shift among them. Primary-secondary analysis apparently requires the courts to inquire into the degree that employer conduct threatens job security, in order to determine the existence of an "immediate" interest and "primary" concern over another unit's security. On this point, Allen Bradley looms large; for there two units of one union in the same city were prevented from aiding each other to reacquire lost jobs. In the shadow of Allen Bradley, the NLRB ${ }^{6 B}$ rejected

62. Baltimore Lithographers Local 2-P (Alco-Gravure), 160 N.L.R.B. No. 90, 63 L.R.R.M. 1127, 1129 (dissent).

63. 386 U.S. 664 (1967).

64. NLRB v. General Drivers Local 968, 225 F.2d 205, 210 (5th Cir.) cert. denied 350

U.S. 914 (1955); Milwaukee Plywood v. NLRB, 285 F.2d 325 (7th Cir. 1960).

65. 386 U.S. at 668 .

66. Retail Clerks Int'l Ass'n, 127 N.L.R.B. 1522 (1960), remanded in part, 296 F.2d 368 
the union defense of primary activity partially on factual findings that the benefit sought, though local in character, would accrue outside the bargaining unit. These cases merge with Ohio Valley Carpenters which established the rule that job preservation for the union as a whole rather than a unit is secondary. ${ }^{67}$

Under the impetus of Woodwork, a sharp break in the Allen Bradley reasoning has come in the Second Gircuit. In NLRB v. Sheet Matal Workers Local $28,{ }^{68}$ a New York City local had refused to install air flow dampers from Milwaukee, insisting on a right to preserve the jobs for manufacturing members of the City local. The NLRB held the refusal secondary on the ground that it sought benefits for non-bargaining unit members. ${ }^{69}$ The Second Circuit reversed on the authority of Woodwork; the absence of a dispute with the Milwaukee employer and the work-preservation purposes were decisive.

It is not easy to reconcile Sheet Metal Workers and Allen Bradley; both cases involved a New York City local's boycotting outside materials to insure the jobs of other local members at the manufacturing stage. The Sheet Metal Workers opinion adduced none of the evidence that in other contexts has bolstered a finding of primary activity: there was no suggestion that contractors and manufacturers coordinated their bargaining activity, that union personnel frequently interchanged jobs, or that a decline in the local manufacturing level would adversely affect the union members in the installation unit. As it stands, the case seems to hold that a bargaining unit is at least as large as the union local; the court's pointed overlooking of the question whether the boycotters were preserving bargaining unit jobs indicates that a much looser test for the unit, and hence for primary activity, is developing. Considering that the 1947 Congress enacted section $8(b)(4)(B)$ at least partly to overrule the Supreme Court's Allen Bradley dictum that the union conduct there would have been lawful but for the conspiracy with local manufacturers, Sheet Metal Workers' contraction of the secondary category makes for questionable statutory interpretation.

A fifth problem arises where the bargaining unit is of very large size, as in the multi-employer situation. In $N L R B$ v. Teamsters Local 38, involving subcontracting clauses, the Ninth Circuit offered the gratuitous observation that "criss-cross" activity, in which one unit enforces

(D.C. Cir. 1961), on remand, 145 N.L.R.B. 307 (1963); Milk Drivers' Union, 141 N.L.R.B.

1237 (1963), enforced, 335 F.2d 326 (7th Cir. 1964).

67. 196 N.L.R.B. 977, 986 (1962).

68. 380 F.2d 827 (2d Cir. 1967).

69. 156 N.L.R.B. 804,811 (1966). 
the rights of another in the multi-employer arrangement, violates the essence of the secondary-activity prohibition.70 It was unclear whether the court referred to the practices actually before it or to "criss-cross" activity generally; if it had the latter in mind, the cases allowing mutual aid under one employer go the other way. And in the multi-employer bargaining unit, contract gains in work-preservation are meaningful only if all unit members have the power to enforce them by "inside" boycott pressure. ${ }^{71}$

An expansion of the multi-employer concept might be most valuable in the prefabrication industry. Heat of Frost Insulators prevented the union from taking offsite jobs performable only in the factory on the ground that they were not traditional work done by unit members.72 Under present law reservation of these factory jobs for the local is secondary because aimed beyond the unit. Union insistence upon a reasonable reconciliation of the interests in job security and innovationpairing new jobs with displaced employees-is legal only where the contractor employing the displaced worker and the offsite manufacturer of the prefabricated product either are the same employer or bargain jointly with the union. Both situations are highly unlikely. To the extent that this application of the primary-secondary distinction prevents unions from securing work in the new process, it exacerbates industrial tensions and creates unnecessary barriers to solutions of an important work-preservation problem.

\section{Right of control}

The employment situation confronting the employee with not one employer, but layers of them, presents special secondary dangers. The employees of a subcontractor who strike or boycott to enforce the provisions of their collective bargaining agreement inevitably affect the general contractor. Is the confrontation directly aimed at the general contractor, making him a primary party, or is the strike effect ancillary to the union's quarrel with the subcontractor? Which is the immediate employer-employee relationship?

Early NLRB cases under section $8(b)(4)(B)^{73}$ established that where-

70. 338 F.2d 23, 28 (9th Cir., 1964).

71. Lewis v. NLRB, 350 F.2d 801 (D.C. Cir. 1965). However, Kroger Co., 148 N.L.R.B. 569 (1964), allowing an employer to exempt himself from clauses of a multi-emplojer contract, weakens any such approach.

72. 139 N.L.R.B. 688 (1962). See also Lewis v. NLRB, 350 F.2d 801, 803 (D.C. Cir. 1965) (discussing unit work and different grades of coal produced by separatc emplojers).

73. Longshoremen's Local 1066, I37 N.L.R.B. 45 (1962); International Longshoremen's Ass'n, 137 N.L.R.B. 1178 (1962), enforced, 331 F.2d 712 (3rd Cir. 1964). These repest passing words from N.L.R.B. v. Denver BIdg. \&: Constr. Trades Council, 341 U.S. 675, 658 (1950). 
ever the general contractor had the legal power to satisfy the demands of the employees while the subcontractor did not, then the general contractor (who has the right of control over the decision) becomes the primary party, the subcontractor a neutral onlooker, and any strike a secondary activity. A long line of cases has unhesitatingly applied the rigid formula. ${ }^{74}$ Even if this rule were theoretically justifiable, the possibilities of flagrant exploitation cast doubt on the rule's viability in a rational world. Consolidated Edison offers an illustrative horrible. ${ }^{\text {t5 }}$ The power company had contracted with a general contractor, reserving the right to withdraw any part of the work at any time. Later on, when union pipefitters charged a violation of their work allocation rights with the subcontractor, Con Ed immediately withdrew the disputed work and assigned it to a different general contractor. The Second Circuit found a union violation of Section $8(b)(4)(B)$.

After Consolidated Edison one wonders whether the subcontractor employee should even bother to bargain for work-preservation rights. The project owner will have no difficulty in writing contract provisions circumventing union safeguards by withdrawal devices or architectural specifications requiring prefabricated materials. The subcontractor may even actively seek such provisions himself.

The notion that the subcontractor lacks control and is a neutral is probably incorrect as an empirical matter; it certainly is undesirable as a conclusion of law when its results lead to such an emasculation of union rights. As Mr. Justice Douglas once noted in dissent:

The presence of a subcontractor does not alter one whit the realities of the situation; ... [a contrary construction of] the TaftHartley Act makes the right to strike, guaranteed by section 13, dependent upon fortuitous business arrangements that have no significance so far as the evils of the secondary boycott are concerned. ${ }^{76}$

The modern primary-secondary analysis requires the complete abandonment of the present "right of control" rule.77 The unit has bar-

74. Journeymen Local 636 v. NLRB, 278 F.2d 858 (D.C. Cir. 1960); Journeymen Local 5 v. NLRB, 321 F.2d 366 (D.C. Cir. 1963), cert denied 375 U.S. 912 (1963); Ohio Valley Carpenters v. NLRB, 339 F.2d 142 (6th Cir. 1964); American Boiler Mfrs. v. NLRB, 366 F.2d 823 .

75. NLRB v. Pipefitters Local 638, 285 F.2d 642 (2d Cir. 1960).

76. NLRB v. Denver Bldg. \& Constr. Trades Council, 341 U.S. 675, 699. See also the dissent of Member Brown in Journeymen Local 5, 137 N.L.R.B. 828, 836 (1962)

77. One writer has suggested that the involvement of the subcontractor in bargatining over these issues should serve to remove his sanctuary as a secondary party. Lesnicle, stipta note 7 , at 1038 . This is too timid. The subcontractor is primary, the gcneral contractor secondary, and a strike upholding bargained-for rights and halting the subcontractor's work (whatever the ancillary effect) is legal. 
gained for its rights and signed a contract with its employer, who happens to be a subcontractor. These two are without doubt the primary parties. The general contractor is removed from this direct confrontation, enters into the picture after the agreement has been made, receives his authority over job placement of the complaining unit derivatively from the subcontractor, and is fully aware of the consequences of such work-preservation agreements. The effects upon the general contractor of any strike in this situation are thus ancillary to a primary dispute with the immediate employer vindicating bargaining unit concerns. This result is required if the right to strike is to be assured to subcontractor's employees.

This reasoning, furthermore, requires no special hardships: the general contractor has adequate notice; machinery exists to mediate any dispute over work between subcontracting units; and the subcontractor is merely estopped from assigning to another party the rights he guaranteed to his orn employees. 